\title{
Development of the creative orientation of the future educator personality through leading social and pedagogical practices
}

\author{
Amina Abtrakhmanovna Niyazova $^{1}$, Tatiana Vladimirovna Korotovskikh ${ }^{1}$, Anastasia \\ Alekseevna Bobrova ${ }^{1}$, German Olegovich Savateev ${ }^{1}$, and Iuliia Maratovna Gibadullina ${ }^{2}$ \\ ${ }^{1}$ Surgut State Pedagogical University, Surgut, Russia \\ ${ }^{2}$ Tyumen State University, Tyumen, Russia
}

\begin{abstract}
Relevance of the Research. The transformations taking place in modern society necessitate the professional training of a mobile, creative educator who is able to creatively approach the development, implementation and development of innovative technologies in the pedagogical process. The Federal State Educational Standard of Higher Education and the Occupational Standard of an Educator make demands on the personality of a modern educator who has creative abilities and the ability to solve pedagogical problems in practice outside the box. Among the competencies of the 21 st century personality, its creativity, which actualizes the process of developing the creative orientation of the future educator, is designated. One of the means of developing the creative orientation of the future educator personality is social and pedagogical practices that ensure the formation of professional skills and the development of creative thinking and cognitive creative activity of future educators. The forms of social and pedagogical practices were volunteer and pedagogical teams, in which socially significant and project activities, developing a creative orientation, creative thinking, and introspection of creative activity, have been identified. The components of the development of the personality creative orientation have been designated: motivational, intellectual-cognitive, reflexive, which formed the basis of the experimental research. The purpose of the research: to theoretically substantiate and to experimentally test the influence of social and pedagogical practices on the creative orientation development of the future educator personality. Research methods: theoretical (analysis of literature, regulatory documents); empirical (study of experience, pedagogical experiment); survey and diagnostic (map of the pedagogical assessment of the educator's abilities to innovative activity (V.A. Slastenin, L.S. Podymova), diagnostics of creative thinking in solving educational problems (I.A. Verchenko, K.Yu. Galushchak, E. Oleinik), the Assessment and Self-Assessment of Professionally Important Qualities technique (N.K. Sergeeva, V.V. Arnautova)); mathematical (methods of statistical processing of research results (F-test (Fisher's criterion))). Research results: the theoretical and methodological approaches to the development of the individual creative orientation have been highlighted; the components of the creative orientation of the future educator personality are developed, positive dynamics has been revealed, and the effectiveness of the use of social and pedagogical practices in the creative orientation
\end{abstract}


development of the future educator, taking into account the methods of mathematical statistics, has been proved. Practical significance: the materials of the paper will be useful to the professional community of lecturers of pedagogical universities and researchers dealing with the problems of developing the creative orientation of the future educator personality.

\section{Introduction}

In modern society, the ongoing transformations cause the need to train a future educator at the university who is capable of a creative approach to mastering, developing, and introducing innovative technologies into the pedagogical process. The process of training a future educator for solving creative pedagogical problems and developing his/her ability to put forward new solutions and to translate them into practice meets the requirements of the Federal State Educational Standard of Higher Education and the Occupational Standard of an Educator in order to improve the quality of education and to develop the creative orientation of the educator's personality.

The development of professional and personal qualities of a future educator is associated with mobility, adaptation to new conditions, efficiency, and a creative approach in solving professional problems, non-standard thinking, and professional competence. It is possible to develop these qualities by increasing motivation, self-development, and selfimprovement in the professional and personal terms, which makes it possible to expand the possibilities for the development of the creative orientation of the future educator personality.

The most significant studies on the study of personality orientation are reflected in the works of Russian (B.G. Ananiev, L.I. Bozhovich, A.N. Leontyev, V.G. Ryndak, O.A. Kalimullina, L.P. Mingazova, and others) and foreign scholars in pedagogy and psychology (E.J. Guilford, K. Taylor, E. Torrance, etc.). Strengthening the development of the personality creative orientation is emphasized in the competencies of the $21^{\text {st }}$ century designated as "soft skills" and associated with the use of a creative approach in working with people [1].

Analysis of the literature has revealed the following prerequisites for the development of the personality creative orientation of a future educator:

- $\quad$ socio-pedagogical, determining the potential of socio-pedagogical practices aimed at the formation of research, design, and analytical skills, as well as the development of pedagogical thinking and cognitive creative activity of future educators;

scientific and pedagogical, which determine the professional training of a future educator for pedagogical activity, shaping his/her creative orientation in the educational environment of the university. In the Federal State Educational Standard, there are no specific competencies aimed at shaping the creative orientation of the future educator personality, therefore, all its components are indicated in general professional and professional competencies;

- scientific and methodological, characterizing the forms, methods, and technologies for the development of creativity and the creative orientation of the future educator personality and the lack of theoretical and methodological development of issues related to the structure and mechanisms of its development, which complicates the construction of education focused on the development of the creative personality of the future educator. 
All these prerequisites determine the high social, scientific, and practical relevance and significance of the development of the creative orientation of the future educator personality.

\section{Materials and methods}

The theoretical and methodological basis for the development of the creative orientation of the future educator personality is the following approaches:

- a philosophical approach that defines sociality and spirituality as components of the creative orientation of personality, individuality and originality (V.I. Andreev, N.A. Berdyaev, V.M. Bekhterev, etc.) [2];

- $\quad$ psychological and pedagogical approach that characterizes the orientation of the personality as a quality associated with the development of creative activity, intellectual and cognitive component, and the formation of motives for creative self-expression in professional activity (B.I. Dodonov, E.P. Ilyin, B.F. Lomov, S.L. Rubinstein, and others) [3];

- a social approach that reflects the main components of creative activity, including target, meaningful, technological, and effective, ensuring the manifestation of creative individuality in the process of interpersonal interaction of educational subjects (N.A. Astashova, S.K. Bondyreva, A.P. Smantser) [4];

- an integration approach that establishes the orientation of the personality as a complex, multi-component concept which includes interests, goals, motives, attitudes, needs, professional knowledge, personal and professional qualities and skills, the relationship of the personality to the world and himself/herself (B.G. Ananiev, A.G. Asmolov, I.I. Rezvitsky, V.I. Slobodchikov, E.I. Isaev, E.L. Yakovleva).

The aforementioned approaches made it possible to determine the vectors of research on the personality creative orientation:

- the first vector that allows us to consider the personality creative orientation as a unique intellectual and cognitive ability for creativity (J. Guilford, K. Taylor, E. Torrance, A.Ya. Ponomarev, and others) [5];

- the second vector, revealing the personality creative orientation as a system of motives and needs that determine the actions and behavior of a person in the social plane (J. Baron, V.S. Merlin, A.A. Ukhtomsky, E.P. Ilyin, and others) [6].

Let us turn to the content of the concept of "personality creative orientation", where the initial is "orientation" as a stable manifestation of needs, motives, and interests conditioned by attitudes towards shaping creative activity, social behavior, and worldview" $[7,8]$.

According to the studies of a number of authors, the following types of orientation are distinguished: humanistic, environmental, moral, axiological, etc. For our research, the concept of "personality creative orientation" is significant as a person's complex ideas about himself/herself and the results of creative activity. A creative person is a personcreator capable of creating something new in his/her activity and embodying them in practice. So, K.K. Platonov substantiates the identity of the educator's creative activity and his/her intellectual potential [9]. According to N.F. Vishnyakova, the development of the creative orientation of the future educator personality includes the following personality traits: creative individuality, initiativity, creative activity, non-trivial approach to solving professional problems [10].

Thus, the development of his/her creative orientation acts as the basis for professional self-improvement and self-development of a future educator [11].

Social and pedagogical practices are one of the means of developing the creative orientation of the future educator personality. Social practice in the field of education is a 
specific technology, which is a constructive, creative activity, during which a person masters social experience, forms interaction skills in a social group and an individual model of social behavior [12]. The leading forms of social practice are volunteering, student selfgovernment, student associations of interests, etc. Pedagogical practices are a kind of human activity to create the necessary conditions for interaction with students, the main directions of which are: the organization of leisure activities, project, research activities, etc. Such advanced pedagogical practices include the School of Counselors, the School of Communicative Interaction, professional skill competitions, the student scientific community, etc.

The participation of the future educator in leading social and pedagogical practices develops the components of the creative orientation of the future educator personality, among which we have identified:

- a motivational component expressing the desire of future educators to be active in the process of professional and personal growth, self-realization, and self-development, revealing the individual characteristics of a future educator and recognition of their creative achievements;

- an intellectual and cognitive component that reveals the features of the creative thinking of a future educator, the ability to find alternative ways to solve professional problems and to see the prospects for one's own professional activity;

- a reflexive component, involving the analysis of satisfaction with the results of professional activity, self-assessment, and introspection in order to achieve efficiency in shaping pedagogical skills and the development of a person's creative orientation.

Based on the presented components, we have determined the criteria for the development of the personality creative orientation and diagnostic methods, which are provided in Table 1.

Table 1. Criteria for the development of the creative orientation of the future educator and diagnostic techniques

\begin{tabular}{|l|l|l|}
\hline Component & \multicolumn{1}{|c|}{ Criteria } & \multicolumn{1}{|c|}{ Techniques } \\
\hline Motivational & $\begin{array}{l}\text { Creative orientation (indicators: } \\
\text { motivational and creative orientation, } \\
\text { creativity, educator creativity, individual } \\
\text { characteristics of the educator's personality) }\end{array}$ & $\begin{array}{l}\text { Map of the pedagogical } \\
\text { assessment of the educator's } \\
\text { abilities to innovative activity } \\
\text { (V.A. Slastenin, L.S. Podymova) }\end{array}$ \\
\hline $\begin{array}{l}\text { Intellectual } \\
\text { and } \\
\text { cognitive }\end{array}$ & $\begin{array}{l}\text { Creative thinking (indicators: fluency, } \\
\text { originality, productivity of creative } \\
\text { thinking) }\end{array}$ & $\begin{array}{l}\text { Diagnostics of creative thinking } \\
\text { in solving educational problems } \\
\text { (I.A. Verchenko, } \\
\text { K.Yu. Galushchak, E. Oleinik) }\end{array}$ \\
\hline Reflexive & $\begin{array}{l}\text { Reflexive skills (indicators: introspection, } \\
\text { auto-evaluation, and attitude to one's own } \\
\text { creative activity) }\end{array}$ & $\begin{array}{l}\text { Assessment and Self-Assessment } \\
\text { of Professionally Important } \\
\text { Qualities technique } \\
\text { (N.K. Sergeeva, V.V. Arnautova) }\end{array}$ \\
\hline
\end{tabular}

Thus, the theoretical analysis of the literature made it possible to characterize the main concepts of the research, to highlight the components, criteria, and indicators of the creative orientation of the future educator personality, under which the diagnostic tools have been selected. Let us move on to describing the research results.

\section{Results and discussion}

The study of the creative orientation of the future educator personality was carried out on the basis of the Budgetary Institution of Higher Education of KhMAO-Yugra "Surgut State Pedagogical University" in the period 2019-2020, which was attended by 134 people- 
students in the following fields of study: "Pedagogical Education", "Special (Defectological) Education", "Psychological and Pedagogical Education".

The primary diagnostics carried out at the ascertaining stage of the study allowed us to identify the following problems:

- not expressiveness of the creative orientation of the future educator personality, lack of creative interest and ability for the educator's professional activity; insufficient understanding of the social significance of creative activity;

- lack of a unified approach to understanding the nature of creative thinking, the manifestation of standardization in solving professional problems;

- lack of reflective analysis skills and an adequate assessment of their own professional activities.

At the shaping stage, taking into account the identified problems, we have implemented leading social and pedagogical practices, which acted as a means of developing the creative direction of the future educator personality. One of the forms of social practice was volunteering aimed at the formation of socially significant and professional qualities, which serves as the basis for the creative orientation of the future educator personality. On the basis of the Budgetary Institution "Surgut State Pedagogical University" (SurSPU), there are volunteer teams "PRO-Dobro", "Heart in the Palm" and pedagogical teams "Cranberry", "Commonwealth", whose activities are aimed at the formation of professional and personal qualities and creative activity expressed in the implementation of two areas of activity: socially significant and project ones.

Volunteer and pedagogical teams have developed and implemented the following projects "Plasticine Crow", "All Dolls Visit Us", "House with a Lighthouse", "3D Dorogoj Dobryh Del (lit. By Way of Good Deeds)", "Peace in Gestures", "Eco-quest 'Peace in Which We Live'", etc., which contributed to the development of the creative orientation of the personality of future educators. The success in the implementation of projects and activities was assessed by each student in an individual reflexive map.

The results of the activities of the volunteer and pedagogical teams are actively presented on the website of the university and the newspaper "Steps". The achievements of students in social and pedagogical practices allowed entering competitions and events of all-Russian (sessions of the University of Inclusive Volunteering "Pro-So", competition of volunteer initiatives "2020 Volunteer of Russia", competition of professional skills "The Best Student Pedagogical Team", competition "Leaders-to-School") and international (competition of youth projects "I Am a Professional", Kazakhstan) levels.

At the control stage of the study, we have carried out a secondary diagnosis of the development of the creative orientation of the future educator personality. Let us analyze the obtained results of the ascertaining and control stages of the research, in accordance with the components of the development of the creative orientation of the future educator personality that we have identified (Fig. 1 and Fig. 2). Thus, the increase in respondents for a high level was:

- on the motivational component - $21.6 \%$ (from $25.4 \%$ to $47 \%$ ), which indicates an awareness of modern progressive trends in education, the need for creative self-realization, a consistently positive attitude towards pedagogical activities;

- on the intellectual and cognitive component - $23.9 \%$ (from $19.4 \%$ to $43.3 \%$ ), which are characterized by: the ability to express original ideas and the originality of creative thinking, an unusual approach to solving professional problems;

- on the reflective component $-17.9 \%$ (from $13.4 \%$ to $31.3 \%$ ), which indicates the presence of reflexive skills in analyzing one's own creative development, a positive attitude to creative activity in its various forms, self-improvement, self-education in the educator's professional activity. 


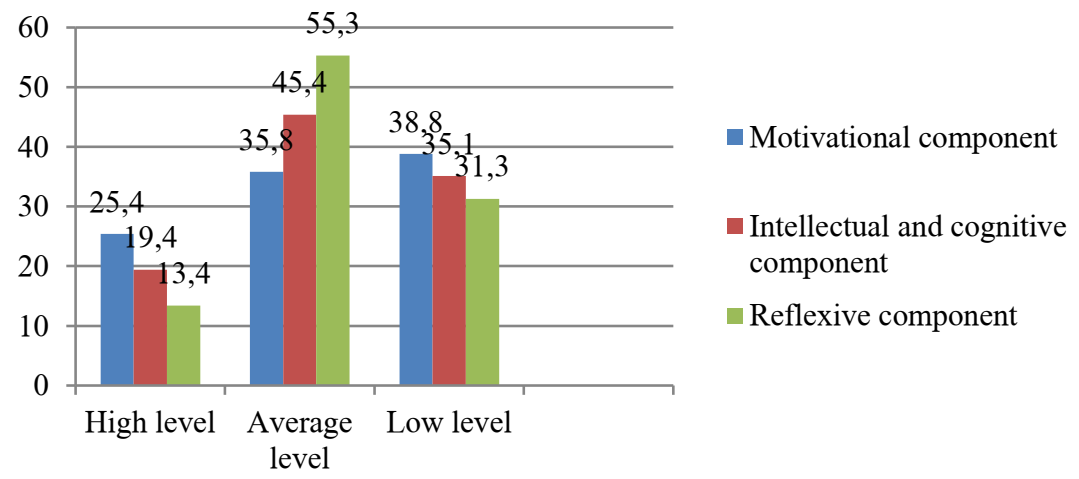

Fig. 1. Assessment of the level of development of the creative orientation of the future educator (ascertaining stage, \%)

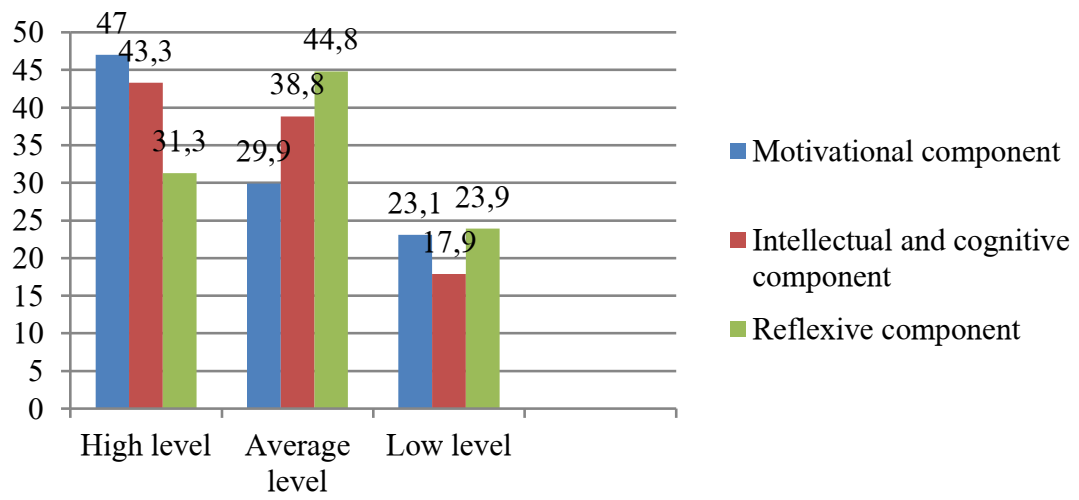

Fig. 2. Assessment of the level of development of the creative orientation of the future educator (control stage, \%)

Thus, the presented results state the dynamics of the development of the creative orientation of the educator personality, which have been statistically processed using the Ftest $\left(\varphi_{\text {эмп }}=3.279\right.$; for $\varphi_{\text {кр }}=2.31$ for $\left.\mathrm{P} \leq 0.01\right)$, according to which the level of development of the creative orientation of the personality of future educators is significantly higher at the control stage than at the ascertaining one.

\section{Conclusions}

Thus, the theoretical analysis of psychological and pedagogical literature made it possible to theoretically substantiate the development of the creative orientation of the educator's personality based on theoretical and methodological approaches and its structural components. In accordance with the identified components, the criteria and indicators for assessing the level of development of the creative orientation of the educator's personality have been determined. An important point in the experimental work was the choice of diagnostic tools that revealed the indicated indicators of the creative orientation of the future educator personality. The main means of developing the creative orientation of the future educator personality were social and pedagogical practices, which made it possible for the manifestation of creativity, originality of thinking, independence, self-improvement in professional activity. The results of the experimental study prove the effectiveness of 
social and pedagogical practices, which are confirmed by quantitative, qualitative, and mathematical processing.

\section{References}

1. T.A. Yarkova, I.I. Cherkasova, Bulletin of Tyumen State University. Humanities Research, Humanities, 2(4), 222 (2016)

2. A.V. Nikitina, Development of the Creative Orientation of the Future Educator Personality by Means of the Subjects of the Aesthetic Cycle, 220 (2002)

3. O.A. Kalimullina, Bulletin "Kemerovo State University of Culture and Arts", 22, 186 (2013)

4. N.A. Astashova, S.K. Bondyreva, A.P. Smantser, Education and Science, 20(7), 32 (2018)

5. E. Torrance, Guiding creative talent - Englewood Cliffs, 260 (1964)

6. J. Baron, Journal of Intelligence, 6(2), 23 (2018)

7. L.P. Mingazova, Development of the Creative Orientation of the Personality of a Participant of the Student Amateur Vocal and Choral Group, 18 (2006)

8. G.M. Kodzhaspirova, Pedagogical Dictionary, 145 (1998)

9. K.K. Platonov, Personality Structure and Development, 256 (1986)

10. N.F. Vishnyakova, Creative Psychopedagogy: The Psychology of Creative Learning, 131 (1995)

11. D.V. Miroshnikova, World of Science. Pedagogy and Psychology, 2(6) (2018) https://mir-nauki.com

12. L.A. Vitvitskaya, D.V. Miroshnikova, Bulletin of Orenburg State University, 10, 34 (2017) 